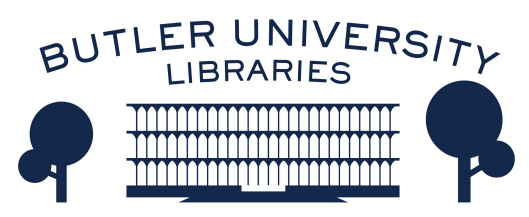

Journal of Hindu-Christian Studies

January 2004

\title{
Core Issues of Hindu-Christian Dialgoue: Idol-Worship, Cow- Protection and Conversion
}

\author{
J.K. Bajaj \\ M.D. Srinivas
}

Follow this and additional works at: https://digitalcommons.butler.edu/jhcs

Part of the Religion Commons

\section{Recommended Citation}

Bajaj, J.K. and Srinivas, M.D. (2004) "Core Issues of Hindu-Christian Dialgoue: Idol-Worship, CowProtection and Conversion," Journal of Hindu-Christian Studies: Vol. 17, Article 5.

Available at: https://doi.org/10.7825/2164-6279.1314

The Journal of Hindu-Christian Studies is a publication of the Society for Hindu-Christian Studies. The digital version is made available by Digital Commons @ Butler University. For questions about the Journal or the Society, please contact cbauman@butler.edu. For more information about Digital Commons @ Butler University, please contact digitalscholarship@butler.edu. 


\title{
Core Issues of Hindu-Christian Dialogue: Idol-Worship, Cow-Protection and Conversion
}

\author{
J. K. Bajaj and M. D. Srinivas \\ Centre for Policy Studies, Chennai
}

MAHATMA Gandhi epitomised the ideal of a believing Hindu in modern times. He was deeply read in the classical literature of Indian civilisation that constitutes the considerable scriptural corpus of Hinduism. But he did not derive his faith from this source alone. His beliefs and practices were derived at least in an equal measure from what the common Hindu of his time believed and practiced. In this respect also he was following the classical discipline.

In Hinduism the prevailing belief and practice among the people is taken to be the valid source of dharma. Thus, the Taittiriyopanishad says: ${ }^{1}$

Whenever you are in doubt about the action or behaviour proper to any context, then do what the

\begin{abstract}
Brahmanas there - those of them who are given to proper deliberation, who are adept in the performance of their karmas, who are not under the direction of others, who follow the straight path and who are solicitous for dharma - do in that context.
\end{abstract}

In contexts that pertain to routine dayto-day living, to the ordinary vyavahara of the world, the authority in fact shifts away from the Brabmanas to the Sudras and Women; being responsible for the proper conduct of vyavahara, they are the repository of valid authority in this domain. The Paramacharya of Kanchipuram, a personage deeply seeped in classical Hinduism and entirely devoted to following

Dr. J. K. Bajaj is currently Director of the Centre for Policy Studies in Chennai. He has a Ph.D. in Theoretical Physics from Punjab University in Chandigarh and has taught and conducted research in various places in India. He is a Member of the Indian Council for Social Science Research, the Governing Body of the National Council of Rural Institutes, and the Advisory Board of the Council for Scientific and Industrial Research. He is editor of Ayodhya and the Future India (Chennai: Centre for Policy Studies, 1993) and co-authored with A. P. Joshi and $M$. D. Srinivas Religious Demography of India (Chennai: Centre for Policy Studies, 2003). Among other works co-authored with M. D. Srinivas is Timeless India Resurgent India: A Celebration of the Land and People of India (Chennai: Centre for Policy Studies, 2001), of which a Hindi version is in press.

M. D. Srinivas is Founder Chairman and Senior Fellow of the Centre for Policy Studies in Chennai. He has a Ph.D. in Theoretical Physics from the University of Rochester. He is or has been a Member of the Advisory Board on History of Science (Modern Period), INSA; the Indian National Commission for History of Science, INSA; and the Central Sanskrit Board. He is also Vice Chairman, Governing Body; of the Indian Institute of Advanced Study, Shimla. Along with co-authorship of the above books, he has written Measurements and Quantum Probabilities (Hyderabad: Universities Press, 2001) and co-edited with $M . S$. Sriram and $K$. Ramasubramanian 500 Years of Tantrasangraha: A Landmark in the History of Astronomy (Shimla: IIAS, 2002). 


\section{J. K. Bajaj and M. D. Srinivas}

the classical discipline, advised a questioner to ask the Sudras and Women about proper practice and conduct in all contexts of ordinary vyavahara. The Paramacharya was echoing the advice given by the highly regarded dharma text, the Apastamba Dharmasutra, which says: ${ }^{2}$

\section{Stribhyah sarvavarnebhyascha dharmaseshan pratiyat ityeke ityeke One should learn the remaining Dharmas from women and people of all varnas, so say some, so say some.}

Mahatma Gandhi was well versed in this tradition and discipline; he conscientiously and consciously followed it; he deliberately tried to model his thoughts and responses on those of an ordinary pious Hindu. This makes him the appropriate authority to consult when trying to understand what the ordinary Hindus of our time feel and believe about dharma, how they react when confronted with other beliefs and practices, what they find

acceptable in the latter and what they find to be beyond the pale.

Mahatma Gandhi proclaimed himself to be a Sanatani Hindu, a Hindu who believed and followed the timeless discipline. Yet he engaged in a continuous and prolific dialogue with Christians at all levels. The dialogue began in childhood and continued throughout his life. All throughout he remains steadfast in his respect for Christianity and the person of Christ; but he is equally steadfast in refusing to accept the uniqueness of the Christian experience or the Christian God, and he vigorously denies the legitimacy of Christian criticism of Hindu beliefs and practices and their right to convert others to their faith. It is perhaps wise to read this dialogue of Mahatma Gandhi as representative of the largely unarticulated dialogue ordinary Hindus have been having with Christianity.
I.

Mahatma Gandhi engages in his continuous and varied dialogues with his own people as well as with others from his secure anchorage in sanatana dharma. To understand his position in various contexts, therefore, it is necessary to understand what being a follower of sanatana dharma means for him.

Mahatma Gandhi offers one of the most succinct definitions of the basic tenets of being a follower of sanatana dharma in an article that he wrote following his visit to Madras and other places in south India during the latter half of September 1921. It was during this visit to the heartland of Hindu orthodoxy that Mahatma Gandhi took upon himself the further penance of wearing only a loincloth to cover his body. In a speech at Madurai on September 22, Mahatma Gandhi took the vow "to discard at least up to the 31st of October my topi and vest and to content myself with only a loincloth and a chaddar whenever found necessary for protection of my body." The single loincloth became the regular dress of Mahatma Gandhi from then onwards, and thus he came to resemble even more a traditional Indian man of religion and divinity.

During this visit to south India, Mahatma Gandhi repeatedly asserted his claim to being a Sanatani Hindu and perhaps meditated much on the meaning of being a follower of sanatana dharma. Immediately following the.visit, he wrote an article in Young India of October 6, 1921 defining his conception of a Sanatani Hindu. The definition he gave then surpasses his usual succinctness and simplicity of language. He wrote: ${ }^{4}$

I call myself a Sanatani Hindu because:

1. I believe in the Vedas, the Upanishads, the Puranas and all that goes by the name of Hindu 
scriptures, and therefore in avataras and rebirth,

2. I believe in the varnashrama dharma in a sense in my opinion strictly Vedic but not in its present popular and crude sense,

3. I believe in the protection of the cow in its much larger sense than the popular,

4. I do not disbelieve in idol-. worship.

These four beliefs and practices that Mahatma Gandhi defines to be fundamental to being a Sanatani Hindu form the basis of the religious commitment and life of an ordinary Hindu. All the four seem to conflict with the beliefs and practices of Christianity. In fact, during Mahatma Gandhi's time, even those of the Hindus who were educated in the Christian-inspired education system of India would have found it difficult to accept these four tenets. In the educated Indian discourse of Mahatma Gandhi's time, belief in Hindu scriptures, varnashrama dharma, sanctity of the cow and idol-worship had become problematic if not disreputable, largely under the influence of Christianity. Some of the religious reform movements that arose in India in response to the perceived threat from Christianity, like the Brahmo Samaj, etc., forcefully rejected one or the other of these.

However; with the passage of time since the first contact with Christianity and with the establishment of Indian rule after Independence, the rejection of these beliefs from within the Hindu fold has gotten muted; educated Hindus have begun to at least tolerate and understand, if not actually practice, these four tenets of Mahatma Gandhi. And even Christians have begun to grant some merit and meaning to the Hindu scriptures, though they continue to firmly reject the other three elements of this list.
II.

We have mentioned Mahatma Gandhi's perception of Hinduism because it seems to us that the dialogue between ordinary Hindus and their conscientious leaders seems to have floundered on the bedrock of precisely the four beliefs that he lists to be of the essence of being a Hindu.

These four beliefs and practices arise from the fundamental understanding of Hinduism about creation and man's place in it. For Hindus all creation, both sentient and insentient, is manifestation of the divine, and man is a mere part of this divine creation. Mahatma Gandhi at another place illustrates this Hindu attitude by referring to the first verse of Isopanishad, which says that

\section{Isavasyamidam sarvam yatkincha jagatyam jagat \\ God pervades everything that is to be found in the universe.}

Mahatma Gandhi calls this "one incredibly simple mantra of the Isopanishad" to be the "essence of Hinduism."

Hindus, thus, tend to see and experience divinity in what, in other cultures, and especially in Christianity, is defined as the ordinary secular world. There has been much metaphysical and theological discussion and debate on these differing perspectives of the Hindus and Christians. The issue has been debated at various levels of sophistication and scholarship, and from various perspectives. In this essay, we do not look at the theological or metaphysical implications of this core differentiating feature of these two great cultural and religious traditions of the world, but only at what this difference has meant to the ordinary people of India and their high representatives.

III.

At the lay level, the Hindu attitude of seeing divinity in the ordinary world finds its most 
striking expression in idol-worship. For the ordinary Hindu, and indeed for the high savants of Hinduism like the great Adi Shankaracharya himself, idol-worship is fundamental to religious practice and experience. Through such worship, Hindus realise and experience for themselves some part of the truth about the unity of all creation that the high texts of Hinduism talk about with such intensity and the different schools of Indian darsana try to propound and explain with great sophistication.

It is true that there have been so-called nirguna sampradayas within Hinduism that have tended to visualise a formless god and rejected idol-worship. But that rejection has often been from a fundamental stance that since the whole world is the home of God, it is erroneous to see His presence in a spatially and temporally circumscribed idol. These nirguna sampradayas in fact give a more intense meaning to seeing divinity in the world; they ask their followers to worship not a specific idol at a specific time, but to worship every aspect of creation with every breath. Being aware of these schools of Indian thought, Mahatma Gandhi carefully formulates his position regarding idol-worship; he does not say that a Sanatani Hindu necessarily practices idolworship - he may be practicing worship of the formless nirguna god - but that he "does not disbelieve in idol-worship".

For Christians and other non-idolatrous people, however, idol-worship of the Hindus is the grossest manifestation of error; it is the visible symbol of their state of error, of the fact that the light of truth has not yet been brought to them. Christians and others refer to idol-worship by the pejorative term of "idolatry;" and they feel a sense of revulsion against "idolatry." On the other hand, Indians seem aesthetically and ethically violated by the contempt and disregard shown by others to what they worship.
IV:

Worship of the cow, seeing a special sanctity in her, and striving for her protection is another and perhaps a highly exalted form of idol-worship. Mahatma Gandhi holds cow-worship to be the symbol of whatever is best in Indian civilisation. In the article on the discipline of a Sanatani Hindu that we have quoted above, he explained the position of the cow in Hinduism thus: ${ }^{6}$

The central fact of Hinduism however is cow-protection. Cowprotection to me is one of the most wonderful phenomena in human evolution. It takes the human being beyond his species. The cow to me means the entire sub-human world. Man through the cow is enjoined to realize his identity with all that lives. Why the cow was selected for apotheosis is obvious to me. The cow was in India the best companion. She was the giver of plenty. Not only did she give milk, but she also made agriculture possible. The cow is a poem of pity. One reads pity in the gentle animal. She is a mother to millions of Indian mankind. Protection of the cow means protection of the whole dumb creation of God. The ancient seer, whoever he was, began with the cow. The appeal of the lower order of creation is all the more forcible because it is speechless. Cowprotection is the gift of Hinduism to the world. And Hinduism will live so long as there are Hindus to protect the cow.

The other two elements of Mahatma Gandhi's list of essential disciplines for a Hindu are also deeply rooted in the essential Hindu understanding of creation and man's place in it. Belief in varnashrama dharma and the Vedas and other classical literature 
of Indian civilisation is essential to the maintenance of the Hindu way of life in the world. For Christians and other outsiders such beliefs were as loathsome as the worship of idols and the cow.

V.

This philosophical, aesthetic and ethical conflict over fundamental beliefs and disciplines of the Hindus seems to have obstructed an open and fruitful dialogue amongst Christians and Hindus at every stage, especially after Christianity began to be widely presented to the Indian people from around the beginning of the seventeenth century and much more intensely from the mid eighteenth century. The missionaries who began large-scale evangelisation in the wake of the imperial conquest of India tended to heap uninhibited insults at all aspects of Hinduism, but especially on the four tenets listed by Mahatma Gandhi and which the Indian people held in high reverence. The Church records in India are full of graphic details of how the missionaries of different denominations vied with each other in reviling the idols of Indian gods, abusing the cow, vilifying the system of varnashrama dharma and maligning the Vedas and other sacred texts of India.

The reviling was so extensive and deep that even those of the Indians who were well-versed, in the fundamentals of other religions and had an attitude of reverence and openness for the religious experiences of other people seemed to have been repelled. Thus Swami Vivekananda was forced to exclaim during his visit to the USA in $1894:^{7}$

You train and educate and pay men to do what? To come over to my country to curse and abuse all my forefathers, my religion, and everything. They walk near a temple and say, 'You idolators, you will go to hell.' ...And whenever your ministers criticise us let them remember this: If all India stands up and takes all the mud that is at the bottom of the Indian ocean and throws it up against the Western countries, it will not be doing an infinitesimal part of that which you are doing to us.

Even a person like Mahatma Gandhi, whose tolerance of others is legendary, recalls his early encounter with missionary teaching with dislike. Describing his childhood experience during school at Rajkot, he writes: ${ }^{8}$

In those days Christian missionaries used to stand in a corner near the high school and hold forth, pouring abuse on Hindus and their gods. I could not endure this. I must have stood there to hear them once only, but that was enough to dissuade me from repeating the experience.

And, referring to the conversion of a well-known Hindu to Christianity, he says: ${ }^{9}$

It was the talk of the town that, when he was baptised, he had to eat beef and drink liquor, that he also had to change his clothes and thenceforward he began to go about in European costume including a hat. These things got on my nerves. Surely, thought I, a religion that compelled one to eat beef and drink liquor and change one's clothes did not deserve the name. I also heard the news that the new convert had already begun abusing the religion of his ancestors, their customs and their country. All these things created in me a dislike for Christianity.

Ordinary Indians did not have the resources or courage to express their resentment the way Vivekananda or 
Mahatma Gandhi could. They perhaps took the missionary revilement of their faith as some eccentricity that did not deserve serious reflection, but they were exposed to this revilement even in the holiest and the most public of their places. Louis Rousslet, a French traveller to India, writing in 1876 , described the scene near Baba Vishwanath temple of Varanasi thus: ${ }^{10}$

And in what country could such a spectacle be witnessed as that which met my eyes that day in this square of Benaras? There, at ten paces from all that the Hindoo holds to be most sacred in religion, between the Source of Wisdom and the idol of Siva, a Protestant missionary had taken his stand beneath a tree. Mounted on a chair, he was preaching in the Hindostani language, on the Christian religion and the errors of paganism. I heard his shrill voice, issuing from the depths of a formidable shirt-collar, eject these words at the crowd, which respectifully and attentively surrounded him - You are idolators; that block of stone which you worship has been taken from a quarry, it is no better than the stone of my house.

The reproaches called forth no murmur; the missionary was listened to immovably, but his dissertation was attended to, for every now and then one of the audience would put a question, to which the brave apostle replied as best as he could. Perhaps we should be disposed to admire the courage of the missionary if the well-known toleration of the Hindoos did not defraud him of all his merit; and if is this tolerance that most disheartens the missionary, one of whom said to me - our labours are in vain; you can never convert a man who has sufficient conviction in his own religion to listen, without moving a muscle, to all the attacks you can make against him.

Church records in India are replete with similar images of missionaries abusing and reviling all that the Hindus considered revered and sacred; of these the most graphic images are probably of the highly regarded William Carey and other Serampore preachers standing on the streets reviling and abusing Jagannatha, the Lord of the Worlds, against whom the missionaries in India had launched a veritable campaign across the continents. ${ }^{11}$.

Ordinary Indians may not have had the inclination or the energy to protest such desecration of what they regarded to be the most sacred. But it certainly left them deeply violated. The impression that an ordinary pious Hindu formed of Christianity was that of a system of impious practices far removed from what they considered to be religiosity.

\section{VI.}

Even though the Hindus in general do not seem to have strongly protested against the desecration of the images of their gods and the reviling of their sacred texts, they did indeed repeatedly and strongly protest the insistence of Christians, as also of Muslims, to kill and eat cow in a fairly demonstrable and public manner. Those of the Muslim rulers who wanted to evolve some kind of modus vivendi with the Hindus and retain some level of public harmony placed restrictions on public killing of the cow. Under the British rule, which in the eyes of ordinary Indians was but Christian rule, cow-killing became rampant and slaughter houses were opened in the public places under state protection. This led to a protest movement which kept the British Empire in India unsteady for more than a decade during the relatively quiet period between the defeat of the First Indian War of Independence of 1857 and the emergence of 
an intense nationalist movement under the leadership of Mahatma Gandhi around 1915.

The anti-kine-killing movement encompassed the whole of north India; everywhere it was led by religious leaders of diverse sampradayas, and everywhere it reflected the exasperation of the ordinary Indians with alien religions that were making the public sphere of India impious in their eyes. ${ }^{12}$ The ultimate suppression of this movement, without in any way addressing the Indian grievance, seems to have further alienated the Indian people from Christianity. It also perhaps created a permanent association in their minds between beef-eating and Christianity, which was so wide-spread that even Mahatma Gandhi seems to have imbibed it in his boyhood, as we saw above.

\section{VII.}

The Indian attitude of experiencing divinity in the ordinary secular world, which is epitomised in idol-worship and respect for the cow, is also reflected in an attitude of respect to all aspects of nature. The Christian insistence on looking upon nature as secular, as devoid of all divinity, is at the root of the modern scientific attitude that looks upon nature as an adversary whose secrets man must unravel in order to control and conquer it. The attitude was described in graphic language by Francis Bacon, who is widely considered the first philosopher of modern science. Laying down a detailed programme for the conquering of nature, he advised man to systematically torture nature to force her to yield her secrets, "put nature on the rack and compel her to bear witness." 13

Modern Christianity to some extent attempts to modulate this adversarial attitude towards nature, by positing that man is created in the image of the divine and has been appointed vice-regent of God on earth; as the vice-regent he has the responsibility to look after and care for the rest of creation, to be a good husbandman. ${ }^{14}$ For the West today, recalling this Christian religious attitude of care for the rest of creation is essential in order to restrain the intrinsic urge of unfettered exploration and constant alteration of nature that resides at the core of modern science and technology. However, for acquiring a sense of respect for nature and her autonomy, it is perhaps essential to look up to the Indian attitude of seeing divinity in all creation.

This is a larger issue, which need not be discussed in further detail here. But, what is significant is that the modern scientific attitude towards nature, which to a great extent is rooted in Christianity, seems not only strange, but also incomprehensible and somehow unwise to even a modern scientifically trained Indian. The attitude would have looked even stranger to ordinary Indians of the eighteenth and nineteenth century, when Christianity began to be offered to Indians at a widespread level. And, it would have further obstructed any meaningful dialogue between ordinary Indians and Christianity.

\section{VIII.}

The Christian insistence on proselytising, on bringing others to what they believe to be the uniquely true faith, is another major cause of concern regarding Christianity in India. Indians do indeed move from one sampradaya to another, even to sampradayas which sometimes claim to be outside the Hindu or Vaidika fold. But such movements are seldom seen as conversions; these are in the nature of efforts made by a seeker to move towards a more intense religious experience and practice without relinquishing his inherited cultural or spiritual heritage. But conversion to Christianity or Islam is seen as an act of repudiation of the heritage. This is so repugnant to the Indian way, that even someone like Mahatma Gandhi, who was the epitome of tolerance, found it intolerable. ${ }^{15}$ 
The insistence of Christianity to convert restricts the possibility of dialogue at all levels. This makes Christianity, in the eyes of Indians, not another sampradaya with which you can discuss and debate, but a threat about which you need to be vigilant.

It is true that in the Indian subcontinent Christianity has not won converts in any sizeable numbers, except in certain specific pockets and amongst specific communities. But, the effort and urge to convert makes even the most benign aspects of Christianity suspect in the eyes of ordinary Indians, and blocks dialogue.

\section{IX.}

It is not that the Christians have not been aware of the fundamental difference between the Indian and the Christian approach towards the ordinary secular world. Some of the high Christian missionaries in India have tried to circumvent the problem by raising some of the Indian idols to the status of Christian icons. And, in several instances this has indeed led to Christianity becoming and looking like another Indian sampradaya. The popular worship of Annai Velankanni in South India is one of the most obvious examples of this. Perhaps this is the direction in which Christianity needs to move to ensure a deeper dialogue.

Unlike in the case of idol worship where Christians in India have sometimes tried to accommodate the Indian point of view, and have occasionally succeeded; they have refused to compromise on their right and duty to convert. Christianity shall probably have to find a way of giving up this insistence also, if it is to become a normal religion: of the Indian people with which they can have an open and uninhibited interaction.

\section{Notes}

1. Taittiriyopanishad 1.11
2. Apastamba Dharmasutra 2.29.15.

3. The Collected Works of Mahatma Gandhi, New Delhi: Publications Division, Gov. of India, Vol 21, p.181. These have been published in a hundred volumes, the first of which appeared in 1958 and the last in 1994. For a somewhat more detailed exposition of Mahatma Gandhi as a follower of Sanatana Dharma, see J. K. Bajaj, "Relevance of Mahatma Gandhi and His Thought in Modern Times," mimeo, June 2000.

4. The Collected Works of Mahatma Gandhi, Vol. 21, p.246.

5. The Collected Works of Mahatma Gandhi, Vol. 64, p.289.

6. The Collected Works of Mahatma Gandhi, cited above, Vol. 21, p.248.

7. Swami Vivekananda's discourse on "Hinduism and Christianity" in The Complete Works of Swami Vivekananda, Mayavati Memorial Edition, Calcutta 1989, Vol.8, pp.211-212.

8. The Collected Works of Mahatma Gandhi, Vol. 39, p.32.

9. The Collected Works of Mahatma Gandhi, Vol. 39, p.33.

10. Louis Rousslet, India and its Native Princes, published in 1876; cited here from Sita Ram Goel, History of HinduChristian Encounters (AD 304 
to 1996), New Delhi: Voice of India, 1996, second edition, pp. 94-95.

11. Incidentally, the government of Independent India issued a postage stamp on Dr. William Carey in 1993 to mark the bicentenary of his arrival in India. This is perhaps a measure of the split that has taken place between the perceptions of the State and the Society in India. See Introduction to J. Bajaj (ed.) Ayodhya and the Future India, Chennai: Centre for Policy Studies, 1993, pp.1-46.

12. For a collection of selected documents on the Anti-KineKilling Movement see Dharampal and T. M. Mukundan, The British Origin of Cow-slaughter in India, Mussoorie, 2002.
13. For a detailed discussion of Francis Bacon's characterization of the attitude of modern science towards nature, see, $\mathrm{J}$. K. Bajaj, "Francis Bacon: The First Philosopher of Modern Science," in A.Nandi (ed.), Science Hegemony and Violence, Delhi: Oxford Univ. Press, 1990, pp. 24-67

14. For a Christian articulation of this response, see Fr. Casimir Gnanadickam, "Building Bridges," in Ayodhya and the Future India, pp.119-149.

15. For an exhaustive compilation of Mahatma Gandhi's extended dialogue with Christianity on the issue of conversion, see Sita Ram Goel, History of HinduChristian Encounters (note 10 above). 